\title{
Utilization Of Whatsapp As A Political Communication Channel For Politicians Padang City
}

\author{
Sumartono, Suwandi Sumartias \\ Student of Doctoral Program of Communication Sciences Padjadjaran University Bandung \\ Lecturer of Faculty of Communication Science Padjadjaran University \\ email : rajoameh1999@yahoo.com
}

\begin{abstract}
This study aims to determine the use of social media Whatsapp (WA) as a political communication channel Member of Parliament of Padang City 2014-2019 to netizen. This research is done through approach of constructive qualitative paradigm by using phenomenology method. Informants were selected through purposive sampling techniques. While the technique of data collection is done through interview, observation, and documentation study. The results show that WA as Social Media has become a new force in political communication. For Members of Parliament of Padang City 2014-2019, WA is not just an information media, but has functioned as a media Silaturahmi (Gathering), Presentation, and Self Image. Even that is not less important is the WA has been used as a media recess. Formally each member of the parliament is given the opportunity to meet with his constituents 3 times a year. Through WA legislative members can meet their constituents at all times. This is a new strategy of legislative members in maintaining the existence of legislative members in the next election. Suggestions in this study, first for legislative members who have used WA as a political communication channel to optimally utilize and continue to expand the existing network. Secondly, for the legislative members who have not used WA or other social media to quickly create a social media account. Therefore, the existence of WA or other social media today has been felt very helpful legislative tasks. Aside from being a media publication and aspiration, social media also serves as a bridge of interaction between legislative members and the community. Through WA or other social media sharing issues in the community can be known quickly so that handling can be done quickly and precisely.
\end{abstract}

Keywords-the utilization of WhatsApp, the channels of political communication, politicians,

\section{INTRODUCTION}

Utilization of social media by legislative members becomes a contemporary phenomenon. Social media is not just a media information from politicians to the community, but has functioned as a media that sustains political activity for politicians. The shifting dominance of conventional media utilization to social media for political activity shows the existence of metamorphosis process which must be observed by politicians. This media metamorphosis also demands the world of politics to be able to capture the potential of the digital age in conducting political communication to the public. Politicians or political actors in Indonesia must now be able to target social media such as blogs, facebook, whatsapp, instagram, or twitter and others in political activities. Given the current community has been plagued by the trend of social media use in social activities.

WhatsApp is the most phenomenal app to have the most users in the world, the WhatsApp app beats the Messenger Messenger app messenger as well as other messaging apps in terms of the largest number of users in the world. From the popularity level of WhatsApp app is then made Facebook acquire applications made Jan Koum and Brian Acton with a fantastic amount of as much as 16 billion US Dollars or about 220 trillion Rupiah.

$$
\text { Utilization of WhatsApp (WA) by }
$$

legislative members becomes an interesting contemporary phenomenon to be studied more further WA is not just being a media information of politicians to the public, but has been functioned as a medium that sustains political activity for politicians. WA has changed the way people communicate ideas and ideas. Traditional media, for example newspapers, magazines, television, and radio, provide information to the public in the form of one-way communication.This phenomenon is different from WA, where WA has revolutionized how to share ideas and information by sharing in online communities and networks. Even in view of Budiman (Member of DPRD Kota Padang), WA has functioned as a recess media that helped form what he called the term Dapil community. 


\section{THEORETICAL STUDY}

The theory used in this study is Phenomenology Theory with the aim of research to find new concepts related to How members of Parliament of Padang City 2014-2019 utilize WhatsApp to support its activities as a representative of the people. Phenomenology Theory is chosen as the basis of this research theory because researchers want to focus attention on the conscious experience of members of Parliament of Padang City 20142019 as a politician in Utilizing WhatsApp. This corresponds to the conception of phenomenological theory.Phenomenology theory states that the process to know the direct experience is the area of discussion of phenomenology.Phenomenology uses direct experience as a way of understanding the world. People know experiences or events by way of knowing them consciously through the feelings and perceptions of the person (Morrisan, 2014: 39).

Maurice Marleau-Ponty (in Littlejohn, 2009: 35) mentions that all my knowledge of the world, even my scientific knowledge, is derived from my own view, or from the experience of the world.Phenomenology seeks to understand how humans construct important meanings and concepts within the framework of intersubjectivity --our understanding of the world is shaped by our relationships with others- (Kuswarno, 2009: 2). Phenomenology assumes that people actively interpret their experiences and try to understand the world with their personal experiences (Littlejohn, 2009: 57). A visible phenomenon is a reflection of reality that can not stand alone, because it has a meaning that requires further interpretation.

\section{RESEARCH METHODS}

The method used in this research is phenomenology. The reason researchers use phenomenology research methods because first, the data used in the form of words or not in the form of numbers in which the researcher tried to express the experience of the informant as it is. This is consistent with the method of phenomenological research proposed by Giorgi (Raco, 2012: 156) that in the method of phenomenology the researcher gives meaning from the experience of the informant gives the meaning of his experience. Second, this study aims to understand the meaning of experience experienced by members of Parliament of Padang City 2014-2019 in using social media. Dahlberg (in Raco, 2011: 55) writes that being in the world is always associated with giving meaning. Whatever we make, and think has a relationship with meaning or meaning in our minds. There is no action and thought unrelated to meaning. It is this meaning and meaning that actually keeps people alive, engaged, and acting.Thus, meaning or meaning cannot be avoided from this life. In essence qualitative research uses a phenomenological approach.This means that researchers go to the field by observing the phenomena that occur in the field naturally. But later that will differentiate each type of research is the focus of research. Is the research focused on culture, phenomena, cases, and so forth.

This study used a study or methodology of phenomenology.According to Stephen W. Littlejohn (2005: 336), phenomenology is an approach that assumes that a phenomenon is not an independent reality. A visible phenomenon is an object full of transcendental meaning. The social world of everyday life where human life is always an intersubjective and full of meaning.

With Thus, the phenomenon understood by man is a reflection of the transcendental experience and the understanding of meaning.From the explanation, it can be mentioned that some keywords in phenomenology are the object, meaning, experience, and consciousness of the individual. All of these plays an important role in the study of phenomenology. So this study is trying to learn experiences from the perspective of members of Parliament of Padang City 20142019 in using or utilizing social media.

This research uses phenomenological method because, as Edmund Husserl (Kuswarno, 2009: 10) states, "with phenomenology we can learn forms of experience from the point of view of people who experience it directly, as if we experienced it ourselves. Phenomenology not only classifies any conscious action taken, but also includes predictions of future action, judging from the aspects associated with it. It all comes from how someone interpreted the object in his experience. Therefore, it is not wrong if phenomenology is also interpreted as the study of meaning, where the meaning is broader than just the language that represents it.

\section{RESULT OF RESEARCH}

\section{A.WhatsApp as Media Gathering}

Utilization of WA by members of Parliament Padang City 2014-2019 begins by understanding the social media applications WA itself both conceptually and in application. All 
informants in the study understood that WA is an online medium without being limited space and time. Anytime and anywhere where connected to the internet we can access social media WA. "Understanding and exploiting WA for me as a member of the legislature becomes a conviction, at least we understand how to use it and use it. Thus Budiman (a member of Parliament of Padang City from PKS Party) understands the WA application. While Muzni Zen (another informant) member of the Padang City Parliament from Gerindra Party said that WA is "a new medium that I think can replace the role of conventional media (especially newspapers). As a board member WA certainly provides benefits and should be utilized as much as possible, especially very useful as a medium of communication with the community. "

While Maidestal Hari Mahesa (Politician from PPP Party which has 3 period become member of DPRD of Padang City from 2004 until now) stated that WA as internet based media which can be used as media spread one's information to others or crowd."For me as a board member, WA as a social media is not just a medium of information to the public but a medium of communication channels that helps my presence as a board member. Maidestal Hari Mahesa informant in this research mentions that WA as a medium of friendship. "For me WA means media relationships (media interaction or of course how we can establish relationships with constituents) or interact with the wider community." In essence, the interaction is synonymous with friendship How do I as a member of the legislature trying to keep the relationship or network with the community. formerly the means of exchanging information is done through print media where communication can not be done reciprocally.Now in accordance with the times or the presence of internet technology social media has become a means of direct communication.With social media we can communicate with the wider community.This is the value of more social media than print or electronic media This understanding is what fosters my confidence that social media can serve as a medium of effective and influential communication channels to the public.That is, I feel no mistake when prefer social media in communicating my existence as a legislator member to the community.

Gathering or interaction through WA or interaction (online) is conditional to be realized in the form of offline gratitude. This is done as a form of appreciation and provides answers to problems or problems faced by society or constituents. Budiman mentions, "my offline interactions do as a follow-up of online interactions.WA Group "Future Padang" and WA group "Dapil" usually become referrals of messages I receive should I follow up with field visits. Even later through the WA group "Padang Future" and WA "Dapil" more and more recess activities. Because, almost every week I make a visit to the community following up on interactions in WA. "

Likewise with Muzni Zen when asked whether to follow up the message of the relationship through WA with netizens. Muzni Zen replied, "japri in WA like a broken road with accompanying photos and clear location I usually follow up. But before I go to the location I always coordinate with a minimum of RT or Lurah local. I do this so that my presence has the support of local officials and at the same time as a form of my honor so that its implementation can run smoothly. There are also people send messages via messenger. Well, if this is usually I ask for help from a support team coming from the same area with people sending messages to find out if I need to come to visit or not. As some poor families once asked for scholarships for their children, I immediately coordinated with BAZDA. Then the BAZDA followed up down to the location and when the handover of my help was present witnessed. But there is also one I did not have time to attend because I was visiting out of the region."

\section{B.WhatsApp as Presentation Media}

Related to WA's meaning for informants, Budiman mentions WA as a presentation medium. for my social media to be a means of showing identity or becoming my selfpresentation. I do not think it is a good sign but as a container of how I run the status as a committed committee member to fight for the interests of society.At the same time also become self-control to keep me in the right corridor as a representative of the people. WA became the media presentation because as expressed Budiman WA can be a media that helps members of the council in disseminating my ideas, ideas, or ideas to the community so directly or indirectly through social media WA I provide political education to the community. For example, through the electoral community often throw ideas in the development of Padang city and ask for participation, input and criticism from the community for the next I make the 
materials of making local regulation or input to the executive.Furthermore Budiman mentions, "for me WA becomes a means of showing identity or become a presentation of myself. I do not think it is a good sign but as a container of how I run the status as a committed committee member to fight for the interests of society. At the same time also be self-control to keep me in the right corridor as a representative of the people."

\section{C.WhatsApp as a Media of Self Image}

For Maidestal Hari Mahesa WA becomes an imaging medium.Maidestal states that for me one of the goals of utilizing social media (WA) is for my self-image to stay awake. In Maidestal's view, "self-image is to safeguard the identity and trust given. Self-image means doing the job as well as possible. What matters when I have been elected to be legislator I do not forget my constituents. "Maidestal further states that:" the way I keep my self-image on social media first, every time I will post a photo of myself or comment re-check and read it first. If I'm sure that what I will post will not cause problems before I post to the WA group. Secondly, trying to maximize the response of posts sent by netizens. Thirdly, if the message is late in nature I answered reply I usually say please ma'af for late reply.

Continue to stay and keep the relationship. Because in my view the relationship is the keyword for people to feel cared for. If I am in Padang as much as possible I am present at official events that I must attend such as recess, musrembang, or field visit. If not official such as wedding invitations, mosque invitations, visiting relatives, or channeling hobby badminton and futsal. "

Meanwhile Budiman took advantage of WA's social media as imaging supposedly in the form of making WA a recess medium."My strategy is simple: how we are able to build uninterrupted communication with the community and community leaders.Building such communication is intense and sustainable. Next I do is to multiply the recess that is not formal. By leveraging WA's social media we seem to have an unlimited recess. "

\section{CONCLUSION}

WhatsApp (WA) as Social Media is an online medium with its users can easily access, share, and create the content of messages in a virtual world.WA can function as Media
Reference, Gathering, and Imaging. The development of WA as a social media is so rapid due to curiosity and everyone feels owning their own media. Before the advent of the digital age, people only get information through electronic media such as television, radio, or through print media such as newspapers, tabloids, or magazines. However, along with the development of the times, now someone when wanting to obtain information tend to switch to social media.

\section{REFERENCES}

Biagi, Shirley, 2010. Media/ Impact, Pengantar Media Massa. Jakarta: Salemba Humanika.

Bogdan, Robert \& Steven J Tailor, 1975. Introduction to Qualitative Research Methodes : A Phenomenological Approach to The Social Science, New York : John Wiley \& Sons.

Denzin, Norman K., \& Yvonna S. Lincoln, 1998. Collecting and Interpreting Qualitative Materials, London : Sage Publication, Inc.

Flew, Terry. 2005. New Media : An introduction, New York. Oxford University Press

Gane, N \& Beer D, 2008. New Media, The Key Concepts, New York : Berg.

Kuswarno, Engkus. 2009. Fenomenologi : Fenomena Pengemis Kota Bandung, Bandung : Widya Padjadjaran.

Lattimore, Dan. 2010. Public Relations : Profesi dan Praktek, Jakarta : Salemba Humanika.

Littlejohn, Stephen W, Karen A Foss, 2014. Teori Komunikasi, Jakarta : Salemba Humanika.

McNair, Brian, 2016. Pengantar Komunikasi Politik, Bandung : Nusa Media.

Nimmo, Dan, 1989. Komunikasi Politik : Komunikator, Pesan, dan Media, Bandung : Remaja rosdakarya.

Nasrullah, Rulli, 2015. Media Sosial, Bandung : Simbiosa Rekatama Media.

Roni, Tabroni, 2012. Komunikasi Politik pada Era Multimedia, Bandung : Simbiosa Rekatama Media.

Schutz, Alfred 1967. The Phenomenology of the Social World. Illinois: Northon University Pres 